\title{
REHABILITATION OF THE LABORATOIRE DE CARBONE 14-DAKAR (SENEGAL) WITH A SUPER LOW-LEVEL LIQUID SCINTILLATION COUNTING SYSTEM
}

\author{
Maurice Ndeye ${ }^{1,2} \bullet$ Oumar Ka ${ }^{1,3} \cdot$ Hamady Bocoum ${ }^{4} \cdot$ Alpha O Diallo ${ }^{1}$ \\ ABSTRACT. Following the passing of Prof Cheikh Anta Diop in 1986, the radiocarbon laboratory (LC14) he created $20 \mathrm{yr}$ \\ earlier at the Institut Francophone d'Afrique Noire (IFAN), Dakar, Senegal, fell into a long hibernation. It took nearly 3 yr to \\ renovate the laboratory and reinstall new equipment in order to return LC14 to full functionality and resume its activity. A \\ new dating system has been implemented around a super low-level liquid scintillation spectrometer from Packard, the Tri- \\ Carb 3170TR/LS, located in an underground room. \\ In this paper, we assess the performance of the dating setup (background level and figure of merit) using known samples from \\ Paris 6 and international standards from the International Atomic Energy Agency (IAEA). After the calibration, the setup was \\ used to study bolé seashells from the Khant area in the northern part of Senegal (West Africa). The aim is to present evidence \\ of the correlation between the transgression of the Nouakchottan $(5500 \mathrm{BP})$ and a few industries in the Khant area. The \\ corresponding ages are difficult to assess and the dates available for this cultural site are randomly distributed, ranging from \\ 4500 to 1500 BP, i.e., a chronological period spanning from the Neolithic to the Iron Age.
}

\section{INTRODUCTION}

In the early 1960s, Prof Cheikh Anta Diop, having just returned to Senegal after completing his doctoral studies in France, set up a radiocarbon laboratory at the Institut Francophone d'Afrique Noire (IFAN) $)^{5}$ (Diop 1964). The laboratory became operational in 1966 and material dating was carried out until the early 1980s using DAK as the lab code (Diop 1971). The activity of the laboratory came to a complete stop in 1986 with the passing of Prof Diop.

In 1999 , the Senegalese government gave the directive to IFAN to rehabilitate the ${ }^{14} \mathrm{C}$ laboratory. It took 3 yr to accomplish the task, from restoring buildings to acquiring new equipment, and the new laboratory became fully operational and ready to resume its dating activity in January 2003.

In this report, we present data collected during the calibration of the counting system using samples supplied by LODYC from the University Paris 6 (France) and from the International Atomic Energy Agency (IAEA). We also present the preliminary results obtained on material extracted from the Khant area in the northern part of Senegal (West Africa) in a study aimed at establishing coherent chronographic sequences for this cultural site.

\section{EXPERIMENTAL SETUP}

The best option for the new carbon dating system at LC14 was to use liquid scintillation spectrometry (Polach 1992) with benzene as the scintillation solvent. The benzene volume used each time corresponded to a weight of $2 \mathrm{~g}$ in a Pico glass vial (standard size $20 \mathrm{~mL}$ ). The scintillators were a bis MSB + Butyl PBD mixture $(6 \mathrm{mg}+6 \mathrm{mg})$. The dating setup was installed in the same underground room as the former system; however, no water overhead was used for reducing the background noise.

\footnotetext{
${ }^{1}$ LC14, Institut Fondamental d'Afrique Noire (IFAN), Université Cheikh Anta Diop, Dakar, Sénégal.

${ }^{2}$ Email: soukouma@hotmail.com.

${ }^{3}$ Corresponding author. Email: oumar_ka@ucad.sn.

${ }^{4}$ Laboratoire Préhistoire-Protohistoire, IFAN, Université Cheikh Anta Diop, Dakar, Sénégal.

${ }^{5}$ The current name is Institut Fondamental d'Afrique Noire.
} 
Counting was carried out using a Tri-Carb 3170TR/SL liquid scintillation analyzer from Packard, driven by the Quanta Smart software under a Windows NT operating system. The counting time used in our program was 100 min per cycle.

Assessment of the $3170 \mathrm{TR} / \mathrm{SL}$ is summarized in Table 1. In the 13-85-keV energy range at an efficiency of $68 \%$ and a background noise of $0.2 \mathrm{cpm}$, the figure of merit $\mathrm{E}^{2} / \mathrm{B}$ is 23,400 . These data clearly show the high performance of the counting system. In the super low-level counting mode using a $\mathrm{BGO}$ (Bi4Ge3O12) detector guard, the background is further reduced down to $0.1 \mathrm{cpm}$ for a comparable efficiency. These values compare favorably with the Wallac 1220 Quantulus LSC as shown in Table 2 (see Hogg: http://www.c14dating.com/quant.html) and the LSC system used at the Zagreb Radiocarbon Laboratory (Horvatinčić et al., these proceedings).

Table 1 Initial assessment of the performance of the liquid scintillation counting analyzer in low-level mode through the factor of merit $\mathrm{E}^{2} / \mathrm{B}$. In super low-level mode, the background noise is further reduced down to $0.1 \mathrm{cpm}$.

\begin{tabular}{llll}
\hline Region $(\mathrm{keV})$ & Efficiency $(\%)$ & Background $(\mathrm{cpm})$ & $\mathrm{E}^{2} / \mathrm{B}$ \\
\hline $13-85$ & 68.55 & 0.2 & 23,400 \\
\hline
\end{tabular}

Table 2 Typical counting performance of a Wallac 1220 Quantulus (http://www.c14dating.com/ quant.html); Benzene weights used: $0.3 \mathrm{~mL}=2.637 \mathrm{~g} ; 3 \mathrm{~mL}=2.637 \mathrm{~g} ; 10 \mathrm{~mL}=10.0 \mathrm{~g}^{\text {. }}{ }^{\mathrm{a}}$

\begin{tabular}{|c|c|c|c|c|c|c|c|}
\hline $\begin{array}{l}\text { Vial volume } \\
(\mathrm{mL})\end{array}$ & $\begin{array}{l}\text { B } \\
(\mathrm{cpm})\end{array}$ & $\begin{array}{l}\text { No } \\
\text { (cpm) }\end{array}$ & $\begin{array}{l}{ }^{14} \mathrm{C} \\
\text { efficiency } \\
(\%)\end{array}$ & $\mathrm{fM}$ & FM & $\begin{array}{l}\operatorname{tmax} \\
(\mathrm{yr})\end{array}$ & $\begin{array}{l}\operatorname{tmin} \\
(\mathrm{yr})\end{array}$ \\
\hline 0.3 & 0.04 & 2.47 & 74.8 & 12.5 & 143,350 & 44,100 & 133 \\
\hline 3.0 & 0.25 & 25.66 & 77.8 & 51.4 & 24.290 & 55,500 & 41 \\
\hline 10.0 & 1.03 & 108.09 & 86.4 & 106.7 & 7260 & 61,300 & 20 \\
\hline
\end{tabular}

${ }^{\mathrm{a}} \mathrm{B}=$ background; $\mathrm{No}=$ derived net $\mathrm{cpm}$ for ${ }^{14} \mathrm{C}$ reference standard, 0.95 oxalic acid; $\mathrm{fM}=$ factor of merit $(\mathrm{No} / \sqrt{\mathrm{B}}) ; \mathrm{FM}=$ figure of merit $\left(\mathrm{E}^{2} / \mathrm{B}\right)$; tmax $=$ maximum determinable age (using 3000-min count time and $2-\sigma$ criterion); tmin $=$ minimum determinable age (using 3000-min count time and $1-\sigma$ criterion).

The improvement of the new system from the one formerly used in this laboratory is around 50-fold when the background noise levels are adjusted.

\section{CALIBRATION OF THE COUNTING SYSTEM}

Since the ${ }^{14} \mathrm{C}$ age of the samples from LODYC was already known, it was possible to determine the initial activity $\left(\mathrm{A}_{0}\right)$ from the activities measured for those samples (Table 3 ). The mean value of $8.56 \pm 0.02 \mathrm{cpm}$ (i.e. around $12.25 \mathrm{dpm}$ ) is in very good agreement with the expected result of 8.6. The tSIE, which is the quench indicating factor, was $650 \pm 20$.

Table 3 Calibration of the LC14-Dakar carbon dating system using already-known samples from LODYC-Paris 6.

\begin{tabular}{llll}
\hline $\begin{array}{l}\text { LODYC } \\
\text { lab code }\end{array}$ & $\begin{array}{l}\text { Age } \\
\text { (BP) }\end{array}$ & Mean activity $(\mathrm{cpm} / \mathrm{g})$ & Initial activity $(\mathrm{cpm} / \mathrm{g})$ \\
\hline 202 & 3695 & 5.408 & 8.566 \\
207 & 1215 & 7.349 & 8.549 \\
205 & 960 & 7.612 & 8.578 \\
\hline
\end{tabular}


Another test for the LSC system was to check the output for different samples used in the IAEA ${ }^{14} \mathrm{C}$ intercomparison exercise (Rozanski et al. 1992). The percentage of modern carbon (pMC) obtained from $\mathrm{C} 1$ (carbonate) and $\mathrm{C} 3$ (cellulose) are shown in Table 3. A complete agreement with the reported values can be seen.

In summary, the above calibration data from the LSC system clearly show the high performance of the new system setup at LC14-Dakar, a laboratory which we would like to present under DK as the new code number.

\section{CASE STUDY: KHANT SEASHELLS}

After the qualification stage of the carbon dating system, the research program that was started relates to the study of seashells from the Khant area, northern Senegal.

\section{Context and Excavations}

The Khant depression is approximately $22 \mathrm{~km} \mathrm{N-NE}$ from Saint-Louis, the main city in northern Senegal $\left(16.5^{\circ} \mathrm{E}, 14^{\circ} \mathrm{N}\right)$, in the vast area corresponding to the delta of the Senegal River (Figure 1). The depression is approximately $14 \mathrm{~km}$ long, about $1.7 \mathrm{~km}$ wide, and is enclosed between 2 Ogolian sand-hill strings. Ravisé discovered the site in 1969 (Ravisé 1970). Her investigations allow one to surmise the complex of Khant could have begun around 5000 BP. However, on the basis of subsequent excavations and the industries evident later on, it is likely that human occupation of the area continued until the Protohistoric period and even later.

Guy Thilmans, who was involved in part of the work of Ravisé et al. (1975) and who continued prospecting the area of the delta, indeed unveiled several Neolithic sites as well as Protohistoric ones. A general chart established by this author makes it possible to realize the importance of anthropic shell accumulations in this zone.

During this work, all the surveys carried out by Ravisé could not be observed, either because of an imprecise localization or because of a location was under the backwater-flooded river bed at the time of the investigations. However, it has been possible to recognize certain excavations carried out on the clusters of the Nouakchottan terrace by piecing together the various reports established by Thilmans and the information received from the local population. They are in the same topographic position as those in which Ravisé identified Khant 2 and collected a human skeleton, which she ascribed to the Neolithic era (Ravisé et al. 1975). More recently, Mbow-Diop (1997) carried out subsequent work on the issue.

Thorough prospecting and study of existing documentation leads to identifying 3 different levels of accumulation along the transverse section of the stream in Khant (East-West section): shallow deposits, deposits on the terrace, and deposits of the Ogolian sand-hill strings.

Natural accumulation, harvests, and shell re-use are extremely old in this area. Accumulations follow the Nouakchottan transgression, with a maximum around 5500 BP. Anthropic accumulations, the subject of this study, cover a longer timespan.

The excavations carried out on the material under study should allow for a better understanding of the chronostratigraphic sequence. 


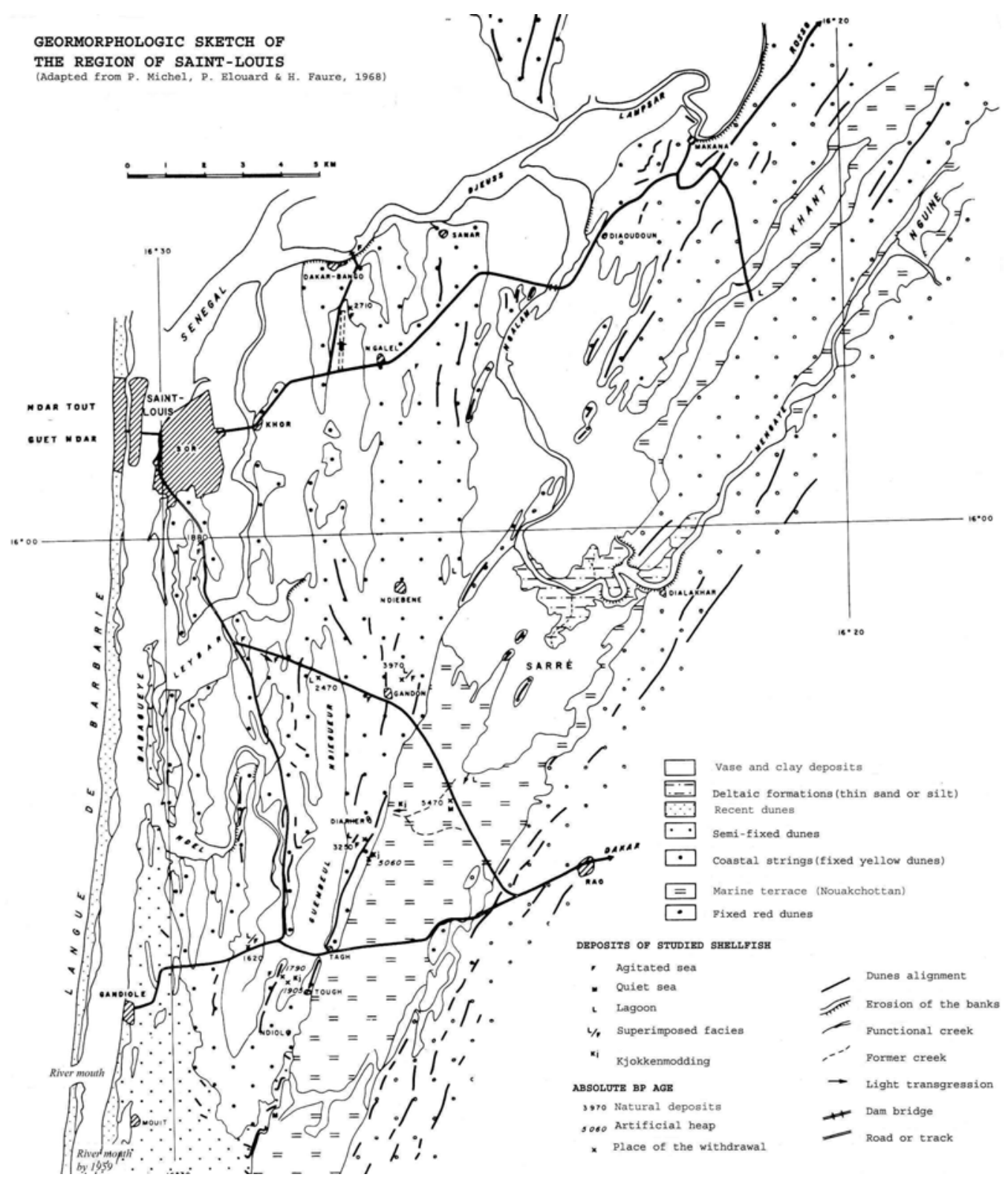

Figure 1 The Khant area in the Saint-Louis region, after Ravisé (1970). Saint-Louis is in northern Senegal, $16.5^{\circ} \mathrm{E}, 14^{\circ} \mathrm{N}$.

\section{RESULTS AND DISCUSSION}

The results presented here deal with the chronological sequence of an anthropic hillock (Bolé zone) together with a measurement relating to a surface-collected material from a close hillock (Xoor nook zone). The excavated hillock has an extension of approximately $140 \mathrm{~m}$ in an E-W axis and $80 \mathrm{~m}$ in a N-S axis. The excavation was done down to a 330-cm depth. The excavated levels are composed primarily of arches and oysters which are sometimes calcined, associated osseous remains, brittle ceramics, and sediment. 
Table 4 shows the chronological sequence obtained with the measurements carried out at LC14Dakar on the Anadara senilis shells collected in the surveys, with a calibration according to Stuiver and Reimer (1993) revision 4.3 of the calibration program. The sequence obtained with DK-1, DK5 , and DK-7 is very coherent: $195-57,409-294$, and 498-336 cal BC ( $1 \sigma)$, respectively. From a preliminary analysis, it can be established that the cluster is constituted very quickly to reach $200 \mathrm{~cm}$ in about 2 centuries (498-294 cal BC). The progression slows down thereafter and the accumulation probably stops at about a century before our era.

Table 4 Percentage of modern carbon (pMC) measured for 2 IAEA samples compared to the mean values derived from the 1990 IAEA C14 intercomparison exercise.

\begin{tabular}{lllrl}
\hline $\begin{array}{l}\text { Sample } \\
\text { code }\end{array}$ & $\begin{array}{l}\text { IAEA 1990 intercomparison } \\
\text { (consensus value) }\end{array}$ & $\begin{array}{l}\text { IAEA 1990 intercomparison } \\
\text { (estimated standard error) }^{\mathrm{a}}\end{array}$ & $\begin{array}{l}\text { LC14-Dakar } \\
\text { LC14-Dakar } \\
\text { (estimated error) }\end{array}$ \\
\hline C1 & $0.00(0.02)^{\mathrm{b}}$ & 0.02 & 0.04 & 0.01 \\
$\mathrm{C} 3$ & 129.41 & 0.06 & 129.36 & 0.07 \\
\hline
\end{tabular}

${ }^{\text {a }}$ This material is considered as a background sample having no measurable activity.

${ }^{b}$ Estimated standard error calculated according to Rozanski et al. (1992).

Table 5 Measured activities, 2S\%, and tSIE values for seashell samples (all samples are Anadara shell) extracted from the Khant area (northern Senegal, West Africa) and the corresponding dates at $1 \sigma$. The calibration was made according to Stuiver and Reimer (1993) revision 4.3.

\begin{tabular}{lllllllll}
\hline $\begin{array}{l}\text { Lab } \\
\text { code }\end{array}$ & $\begin{array}{l}\text { Sample } \\
\text { code }\end{array}$ & $\begin{array}{l}\text { Depth } \\
(\mathrm{m})\end{array}$ & $\begin{array}{l}\text { Activity } \\
(\mathrm{cpm} / \mathrm{g})\end{array}$ & $2 \mathrm{~S} \%$ & tSIE & BP & $\begin{array}{l}{ }^{14} \mathrm{C} \text { age } \\
\text { BP }\end{array}$ & $\begin{array}{l}\text { Cal age } \\
\text { BC }\end{array}$ \\
\hline DK-1 & Khant GPS & 0.3 & 6.7052 & 5.35 & 650.21 & $2448 \pm 34$ & $2144-2006$ & $195-57$ \\
DK-4 & Khant & 2 & 6.3366 & 6.14 & 651.46 & $2633 \pm 29$ & $2358-2243$ & $409-294$ \\
DK-5 & Khant & 3.2 & 6.5608 & 5.30 & 649.40 & $2663 \pm 49$ & $2447-2285$ & $498-336$ \\
DK-7 & Xoor Nook & 0 & 6.7052 & 5.35 & 648.27 & $2912 \pm 29$ & $2748-2647$ & $799-698$ \\
\hline
\end{tabular}

The study of the survey composition makes it possible to understand relatively well the noticeable acceleration during the first 2 centuries. It is explained primarily by the prevalence of the oysters, which have a more significant volume at the beginning of accumulation. The higher levels, which are more compact, are dominated by the arches with an important sandy component, hence, a higher density.

The collected material does not deliver any metal that can be ascribed to the Iron Age. On the other hand, an adze and some bone-made objects were collected. These objects are culturally closer to those evidenced by Ravisé (1970) and this would bring them closer to a final Neolithic era.

In the case of the Xoor nook sample (DK-4), with a collection operated using just a superficial scouring, the age obtained is $888-698 \mathrm{cal} \mathrm{BC}(1 \sigma)$. This result is an incentive for further investigations to confirm that the early stage of this cluster, which culminates at $4 \mathrm{~m}$, could be in the 2 nd millennium BC. One would then be even nearer to the chronological sequences suggested by Ravisé $(1970,1975)$. However, when widening the perspective, one can note that in central Senegal, the Iron Age begins at the same time (Dème 2003). We are perhaps at a transitional period that would mark the end of the Neolithic and announces the introduction of the Iron Age in the Senegal River valley. For this reason, the extension of the investigations and the resulting additional dates of the chronological sequence should contribute to a better understanding of the Khant cultures from the Neolithic to the Iron Age. 


\section{CONCLUSIONS}

The data presented here establish that the new carbon dating system setup at LC14-Dakar is a highperformance tool for the scientific community. Because of the reduced background level, the ${ }^{14} \mathrm{C}$ age may be calculated with a good precision. Thus, the carbon dating service available seems highly competitive.

Preliminary investigations have also been carried out on seashells from a cultural site in the northern part of Senegal. The results obtained are very promising and should lead to a comprehensive understanding of the chronological sequence for different entropic levels with ages spanning from the Neolithic to the Iron Age.

\section{ACKNOWLEDGEMENTS}

The authors would like to thank J-F Saliège (LODYC Paris 6, France) and J-F Tannau and M Fontugne (CEA Gif-sur-Yvette, France) for their tireless assistance during our efforts to rehabilitate the laboratory. The continuous support from the Director of IFAN is to be mentioned as well. We are also grateful to C B Gaye (AIEA, Vienna) for supplying the AIEA samples. The Khant excavation were carried out during a collaboration between $\mathrm{H}$ Bocoum and $\mathrm{R}$ Vernet, with the financial support of the French Ministry of Foreign Affairs.

\section{REFERENCES}

Dème A. 2003. Archeological investigations of settlement and emerging complexity in mid-Senegal valley: excavation at Walaldé [PhD dissertation]. Houston: Rice University.

Diop CA. 1964. Annual report 1963-1964. Institut Fondamental d'Afrique Noire (IFAN), Université de Dakar. p 20-4.

Diop CA. 1971. Centre de datation de l'IFAN. Datation par la méthode du radiocarbone, série I et II. In: Bulletin de l'IFAN série B, tome XXXIII, nr 3. p 449-60.

Hogg A. Wallac 1220 Quantulus, Liquid Scintillation Spectrometer: Performance Data. University of Waikato. (http://www.c14dating.com/quant.html)

Horvatinčić N, Barešić J, Krajcar Bronić I, Obelić B. 2004. Measurement of low ${ }^{14} \mathrm{C}$ activities in a liquid scintillation counter in the Zagreb Radiocarbon Laboratory. Radiocarbon, these proceedings.

Mbow-Diop MA 1997. Les amas coquilliers du delta du
Sénégal: étude ethno-archéologique [PhD dissertation]. Paris: University Paris 1.

Polach HA 1992. Four decades of LS counting and spectrometry. In: Taylor RE, Long A, Kra R, editors. $R a$ diocarbon After Four Decades. An Interdisciplinary Perspective. New York: Springer-Verlag. p 242-61.

Ravisé A. 1970. Industries en os de la région de SaintLouis. Notes africaines 128:98-102.

Ravisé A, Thilmans G, Marius C. 1975. Etude d'un squelette néolithique de la région de St Louis. Bulletin IFAN 37:687-701.

Rozanski K, Stichler W, Gonfiantini R, Scott EM, Beukens RP, Kromer B, van der Plicht J. 1992. The IAEA C14 intercomparison exercise 1990. Radiocarbon 34(3):506-19.

Stuiver M, Reimer PJ. 1993. Extended ${ }^{14} \mathrm{C}$ database and revised Calib $3.0{ }^{14} \mathrm{C}$ age calibration program. Radiocarbon 35(1):215-30. 